Jurnal Tarbawi: Jurnal Ilmu Pendidikan

p-ISSN:1858-1080 | e-ISSN: 2615-6547

Vol. 15, No. 02, Desember 2019, pp. 223-231

\title{
Pendidikan Holistik Berbasis Kecerdasan Ruhiologi di Era Revolusi Industri 4.0
}

\author{
Iskandar $^{1}$, Aletmi $^{2}$, dan Dedi Sastradika ${ }^{3}$ \\ ${ }^{1,2,3}$ Universitas Islam Negeri Sultan Thaha Saifuddin Jambi \\ e-mail: iskandar@uinjambi.co.id ${ }^{1}$, aletmialfaqir90@yahoo.co.id ${ }^{2}$, dedisastradika@gmail.com³
}

\begin{abstract}
Abstrak. The Era of the 4.0 Industrial Revolution has affected a significant change in the educational world, especially the technological influence on human life, has also resulted in a multidimensional crisis that stems from the modern human spritual crisis, the spritual values that became the main cornerstone of the moral formation to be neglected. Holistic education through integrating buman intelligence that includes IQ, EQ, and SQ with RQ is a must. Rubiology Intelligence (RQ) is the intelligence that originates from the buman side of the science of the spirit. This intelligence is the earliest human-owned intelligence that is the source of the three intelligence of IQ EQ and SQ. The Rubiology Intelligence (RQ) is intelligence derived from a vertical (buman-spirit) relationship through religious knowledge of nonphysical material. It is certainly different from many other intelligences such as IQ EQ and SQ which are often free of value (physical material) so as to make people lose the peace of life. The purpose of this research is to build intelligence (IQ, EQ, and SQ) through integrating holistically with Rubiology intelligence (RQ). This research uses a descriptive-analytical approach through a research library research with data analysis techniques conducted only to the extent of the description, namely analyzing and presenting the facts systematically so that it can be easier to understand and conclude. The results of the study showed that there was a side in the buman (non physical material) that came from God as the main mover in character formation. The inside side is the spirit. Ruh plays a big role in the formation of one's sprituality compared to the intelligence of IQ, EQ and SQ which is still a material spirit. To achieve this rubiology intelligence required a vertical relationship between human beings with the creator of the spirit that is Allah SWT through the means of prayer worship. The implications of Rubiology Intelligence (RQ) can solidly strengthen this intelligence (IQ EQ, SQ) will be evident from the changes in sexual behaviour.
\end{abstract}

Kata kunci: Revolusi Industri, IQ, EQ, SQ, Kecerdasan Rubiologi (RQ)

\begin{abstract}
Abstrak. Era Revolusi Industri 4.0 memberikan dampak perubahan yang signifikan terhadap dunia pendidikan terutama pengaruh teknologi terhadap kehidupan manusia, juga telah menimbulkan krisis multidimensional yang bermuara dari krisis spritual manusia modern, nilai-nilai spritual yang menjadi landasan utama dari pembentukan akhlak menjadi terabaikan. Pendidikan holistik melalui mengintegrasikan kecerdasan manusia yang meliputi IQ, EQ, dan SQ dengan RQ menjadi keharusan. Kecerdasan ruhiologi (RQ) adalah kecerdasan yang berasal dari sisi dalam manusia yaitu ilmu ruh. Kecerdasan ini merupakan kecerdasan awal yang dimiliki oleh manusia yang merupakan sumber dari ketiga kecerdasan IQ, EQ, dan SQ. Kecerdasan ruhiologi (RQ) adalah kecerdasan yang berasal dari hubungan vertikal (Manusia-Ruh-Tuhan) melalui pengetahuan Agama yang bersifat nonfisik material. Hal ini tentu berbeda dengan banyak kecerdasan lainnya seperti IQ, EQ, dan SQ yang seringkali bebas nilai (bersifat fisik material) sehingga membuat manusia kehilangan ketenangan dalam hidupnya. Tujuan penelitian ini adalah membangun kecerdasan (IQ, EQ, dan SQ) melalui mengintegrasikan secara Holistik dengan kecerdasan ruhiologi (RQ). Penelitian ini menggunakan pendekatan deskriptif-analitis melalui penelitian library research dengan teknik analisis data dilakukan hanya sampai pada taraf deskripsi, yaitu menganalisis dan menyajikan fakta secara sistematik sehingga dapat lebih mudah untuk dipahami dan disimpulkan. Hasil penelitian memperlihatkan adanya sisi dalam manusia (non fisik material) yang berasal dari tuhan sebagai
\end{abstract}


penggerak utama dalam pembentukan karakter/akhlak. Sisi dalam itu adalah ruh. Ruh berperan besar dalam pembentukan spritualitas seseorang dibandingkan dengan kecerdasan IQ, EQ, dan SQ yang masih berupa spirit material. Untuk mencapai kecerdasan ruhiologi ini diperlukan hubungan yang vertikal antara manusia dengan pencipta ruh itu sendiri yaitu Allah swt melalui sarana ibadah shalat. Implikasi dari kecerdasan ruhiologi (RQ) dapat mengerakkan kecerdasan (IQ, EQ,SQ) ini akan terlihat jelas dari perubahan akhlak/tingkah laku.

Kata Kunci: Revolusi Industri, IQ, EQ, SQ, Kecerdasan Ruhiologi (RQ)

\section{PENDAHULUAN}

Lahirnya peradaban modern di abad ke-20 sebagai dampak dari kemajuan sains dan teknologi yang pesat luar biasa telah menjanjikan berbagai kemajuan dan kemudahan bagi mereka yang berhasil memenuhi segala tuntutan modernisasi. Di lain pihak, akhir abad ke-20 ditandai pula dengan berbagai bencana dan kemelut yang meresahkan hampir semua bidang kehidupan sosial dan pribadi (Bastaman, 1995). Ini karena modernisasi, industrilisasi, dan perubahan-perubahan sosial yang serba cepat dapat mempengaruhi nilai kehidupan masyarakat, sementara tidak semua orang mampu menyesuaikan diri dengan perubahan-perubahan tersebut, pada gilirannya dapat menimbulkan ketegangan atau stres pada dirinya. Perubahan-perubahan sosial yang seringkali bercorak sekuler telah mengakibatkan dehumanisasi, yaitu menurunnya nilai kemanusiaan (Hawari, 1997).

Inilah tema penting mengenai situasi kemanusiaan yang sering dibicarakan di era revolusi industri 4.0. Manusia menghadapi bermacam-macam persoalan yang benar-benar membutuhkan pemecahan segera. Terkadang kita merasa bahwa situasi yang penuh problematik di dunia modern justru disebabkan oleh perkembangan pemikiran manusia sendiri. Hipotesisnya adalah: "Di balik kemajuan ilmu dan teknologi, dunia modern sesungguhnya menyimpan suatu potensi yang dapat menghancurkan martabat manusia."(Kuntowijoyo, 1999).

Bahkan jika diurutkan secara lebih rinci maka akan didapatkan daftar yang amat panjang mengenai berbagai kemelut yang melanda manusia modern saat ini. Contoh pertama, dan mungkin yang terbesar adalah krisis lingkungan. Ekosistem alam kini berada dalam keadaan yang amat labil, efek rumah kaca akibat makin banyaknya gas karbondioksida hasil pembakaran bahan bakar fosil telah mengancam seluruh dunia. Menipisnya lapisan ozon atmosfer karena gas-gas yang dilepaskan pada penggunaan penyegar, misalnya deodoran, dan aerosol. Atmosfer di Eropa saat ini mendapat tambahan sulfur satu gram lebih tiap satu meter persegi sebagai polusi udara yang bisa mengakibatkan hujan asam lalu merusak hutan-hutan dan perairan. Tanah-tanah produktif di dunia ketiga berubah menjadi gurun dengan kecepatan yang mencengangkan, setiap tahun enam juta hektar tanah produktif berubah menjadi gurun. Penyakit minamata di Jepang disebabkan oleh limbah methylmercuri (MeHg). Hal yang lebih dahsyat lagi yaitu setelah peneliti sains memiliki 
kemampuan untuk menciptakan bentuk kehidupan baru lewat rekayasa genetika, maka pada April 1987 kantor Hak Cipta Amerika Serikat mengumumkan bahwa organisme hidup ini -termasuk binatang- dapat diberikan hak paten. Kalau memang manusia telah mampu menciptakan suatu organisme hidup yang baru, lalu dimanakah peran Sang Pencipta? Bidang psikologis juga mengalami hal yang cukup mengkhawatirkan yaitu meningkatnya statistik penderita depresi, kegelisahan, psikosis, dan sebagainya. Tingkat penderita penyakit jiwa dan pelaku bunuh diri meningkat dengan pesat (Ghulsyani, 1996).

Menurut Sayyed Hosein Nasr salah satu akar permasalahan krisis multidimensional manusia modern adalah krisis spritual. Hosein Nasr berpendapat krisis multidimensional disebabkan tiga hal, yakni terabaikannya nilai dan ajaran suci dalam tradisi sehingga memunculkan krisis identitas. Berkurangnya, atau bahkan hilangnya, fungsi dan peran agama dalam kehidupan sosial manusia modern sebagai akibat dari begitu kuatnya mereka memanfaatkan fakultas akal dan rasio serta logika yang pada dasanya hanya mampu memahami obyek fisik; sehingga obyek metafisik tidak lagi menjadi bagian penting. Pengabaian manusia modern terhadap agama menjadi sebab munculnya krisis spiritual. Sementara, cetak biru sains modern terputus secara total dari wahyu serta dari nilai dan ajaran suci yang terkandung dalam tradisi dan agama, merupakan pemicu signifikan lahirnya krisis lingkungan.

Apa yang dikemukakan oleh Nasr juga pernah mejadi laporan yang termuat dalam majalah Time pada edisi khusus terbitan musim gugur tahun 1992. Isi laporan tersebut mengenai masalah masa depan dunia. Penelitian yang menggunakan kebanyakan orang Amerika, Eropa, dan Jepang sebagai sumbernya mengedepankan empat masalah: Pertama, menurut Anda apakah keadaan dunia pada abad ke-21 akan lebih baik dari sekarang? Untuk pertanyaan ini diperoleh jawaban: 41\% mengatakan akan lebih baik, 15\% mengatakan tidak jauh berbeda, dan 32\% mengatakan bahwa keadaan dunia pada abad ke-21 dan seterusnya akan lebih buruk. Kedua, Negara manakah yang akan berpengaruh terhadap dominasi Amerika pada abad ke-21? Diperoleh jawaban: Jerman $7 \%$, Irak 7\%, dan Jepang $22 \%$. Ketiga, Dibanding abad ke-20, peristiwa apakah yang paling banyak terjadi di dunia pada abad ke-21? Untuk pertanyaan ini diperoleh jawaban: perang $21 \%$, kerusakan alam 59\%, kemiskinan $61 \%$, penyakit 53\%, hilangnya harapan tentang masa depan $62 \%$. Keempat, apakah agama akan memainkan peranan penting setelah tahun 2000? Untuk pertanyaan ini diperoleh jawaban: agama akan lebih besar peranannya 53\%, dan yang memperkirakan bahwa peranan agama akan semakin kecil 37\% (Harahap, 2015).

Persentase ini menunjukkan bahwa agama memiliki peran penting dalam mengatasi krisis multidimensional. Secara tidak langsung ini menunjukkan kepada kita bahwa krisis multidimensional yang menimpa umat manusia pada dasarnya berawal dari krisis spritual yang 
disebabkan oleh pengabaian nilai-nilai agama. Lebih jauh Hosein Nasr menawarkan kepada manusia modern dalam menyelesaikan masalah krisis identitas dengan kembali mereevaluasi konsep humanisme modern dan memposisikan fitrah sebagai pusat diri. Jawaban untuk krisis spiritual adalah menumbuhkan kesadaran akan signifikansi peran dan fungsi agama dalam kehidupan baik sebagai individu maupun komunintas. Sementara solusi untuk krisis lingkungan adalah perlu adanya reorientasi peran sains modern serta revitalisasi scientia sacra yang dapat mendorong seseorang memahami bahwa kosmos tidak hanya berdiri secara independen, melainkan memiliki hubungan yang erat dengan dimensi transenden. Dengan begitu, pemanfaatan alam dan lingkungan tidak akan mengabaikan prinsip-prinsip ekologis dari perspektif tradisional, yang berpotensi dapat menghancurkan tatanan ekosistem nature itu sendiri, melainkan tetap pada jalur dan prinsip untuk senantiasa melestarikannya.

Solusi yang ditawarkan oleh Hosein Nasr ini menunjukkan adanya peran sentral relasi spritual antara manusia dengan penciptanya, yaitu Tuhan. Pembelahan struktural kehidupan spritual dari dunia material akan menimbulkan banyak masalah seperti kerusakan ekologi, dehumanisasi atau keterasingan manusia terhadap dirinya sendiri, maupun desakralisasi hidup keluarga dan kesenjangan sosial serta eksploitasi sistematik kelompok kecil manusia atas sebagian lainnya (Mulkhan, 1995).

Di sini, peran agama semakin nyata sebagai pengendali sikap dan perilaku kehidupan manusia, juga sebagai landasan moral, etik dan spritual masyarakat modern di tengah kemajuan ilmu pengetahuan dan teknologi dengan segala dampaknya, baik yang bernilai positif maupun negative (As-Shouwy, 1997).

Melihat betapa urgen nya peran agama di abad modern, maka tidaklah berlebihan jika RAND Corporation yaitu sebuah lembaga kajian yang dibayar untuk memberikan masukan bagi pemerintah AS pernah melaporkan adanya kesadaran masyarakat dunia untuk kembali kepada ajaran Islam (Tauhidi, 2015).

Bahkan al-Qur'an menyatakan bahwa mereka yang tidak mengikuti nilai-nilai ajaran agama akan mengalami kehidupan yang "gelap dan sempit", atau stres, nama yang diberikan di masa kini. Allah swt. berfirman:

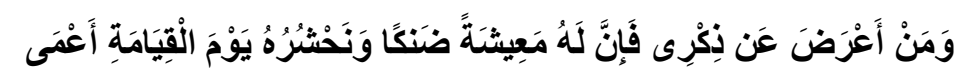

"Dan barangsiapa berpaling dari peringatan-Ku, maka sesunggubnya baginya penghidupan yang sempit, dan Kami akan mengbimpunkannya pada hari kiamat dalam keadaan buta...” (QS. Thaha:124)

Dalam ayat lain, Allah swt. menyatakan:

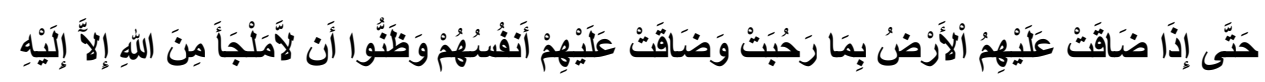


“... Hingga apabila bumi telah menjadi sempit bagi mereka, padahal bumi itu luas dan jiwa mereka pun telah sempit (pula terasa) oleh mereka, serta mereka telah mengetahui bahwa tidak ada tempat lari dari (siksa) Allah, melainkan kepada-Nya saja...” (QS. At-Taubah:118)

Sebagaimana dinyatakan dalam dua ayat di atas bahwa kehidupan yang gelap dan sempit adalah dampak negatif dari spritualitas manusia yang buruk. Hal ini mengindikasikan adanya hubungan yang erat antara jiwa dengan jasad. Ilmu yang membahas masalah ini disebut psikomatik, yaitu masalah yang banyak membicarakan tentang pengaruh keadaan hidup manusia (life situation) kepada jiwa dan raganya, khususnya pengaruh jiwa (emosi) pada badan (Nasution, 2001).

Sekarang manusia modern sadar akan pentingnya spritualitas. Dia harus kembali mencari jiwanya sebab telah terasingkan dari sumber-sumber pembentuknya. Dia terasingkan dari Allah swt. dari penciptaan dan tradisi, atau dengan kata lain terasingkan dari sumber-sumber yang menjadikannya sadar tentang sifat dasar spritualnya akan mengharuskannya kembali pada sumbersumber pembentuknya (Yasien Mohamed, 1996).

Untuk mencapai hal ini semua, maka diperlukan sebuah pendekatan yang bersifat spritual dalam rangka membina dan mengarahkan manusia menuju kepada sumber pembentuknya itu. Pendekatan ini nantinya akan menyentuh sisi dalam manusia yang merupakan faktor inti dari seluruh tindakan dan pemikirannya yaitu "Ruh".

\section{METODE}

Metode penulisan dalam jurnal ini menggunakan pendekatan deskriptif-analitis melalui studi riset kepustakaan (library research), yaitu penelitian yang dilakukan dengan mengumpulkan data dan informasi dengan membaca, menelaah kemudian menganalisis literatur- literatur yang berkaitan dengan tema, baik yang bersifat primer (primary sources) maupun sekunder (secondary sources). Analisis data dilakukan hanya sampai pada taraf deskripsi, yaitu menganalisis dan menyajikan fakta secara sistematik sehingga dapat lebih mudah untuk dipahahami dan disimpulkan.

\section{TEMUAN}

Hasil penelitian ini menunjukkan bahwa sisi dalam manusia (ruh) menempati posisi sentral dalam membentuk tiga kecerdasan manusia: IQ, EQ, dan SQ. Tiga kecerdasan tersebut tidaklah berdiri secara terpisah sebagaimana yang dipahami oleh para penulis lainya tetapi kembali 
kepada satu unsur yang berdiri sendiri secara indevenden dalam diri manusia yaitu ruh yang digerakkan langsung oleh tuhan, sebagaimana dalam dijelaskan dalam Surat As-Sajadah ayat 9:

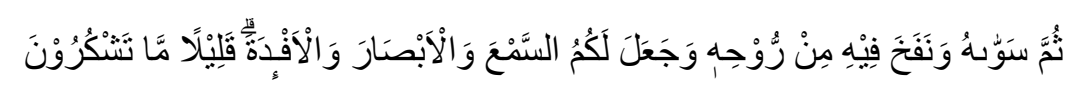

“Kemudian Dia menyempurnakannya dan menyiupkan Ruh ciptaan-Nya kedalam tubuh manusias dan Diajadikan pendengaran, penglihatan dan hati bagimu, (tetapi) sedikit sekali kamu bersyukur" (Q.S.AsSajadah ayat: 9).

Kecerdasan ruhiologi (RQ) dihasilkan dari relasi vertikal antara manusia dengan Tuhan melalui sarana ibadah shalat. Dengan mengetahui hakikat shalat dan tujuan shalat yang benar maka secara individual seseorang telah melakukan prosesi pendidikan holistik dan akan sampai pada kecerdasan ruhiologi. Implikasinya akan tampak pada perubahan tingkah laku/akhlak.

Hasil penelitian ini sejalan dengan temuan ahamad ushuluddin dalam disertasinya menyatakan bahawa pendidikan holistic dalam pendidikan dan kesehatan merupakan alternative baru yang mengkombinasikan kecerdasan Intelektual (IQ), Kecerdasan Emosional (EQ), Kecerdasan Spritual SQ), dalam praktek dilapangan dibidang pendidikan kesehatan sudah menyentuh aspek holistik yang memandang penting dimensi spiritual sebagai pusat diri (rohani) namun masih bersifat "spirit" yang masih berupa material (saraf otak atau neurosains) yang tidak terkait dengan tuhan. Kecedasan (IQ, EQ dan SQ)sebagai basis material, sedangkan Kecerdasan Ruhioligi berbasis immaterial yang langsung berasal dari tuhan (Sugiarto, 2019).

Tujuan penelitian ini adalah membangun kecerdasan (IQ, EQ, dan SQ) melalui mengintegrasikan secara holistik dengan kecerdasan ruhiologi (RQ). Secara teoritis, implikasi dari kecerdasan ruhiologi memberikan kontribusi positif bagi pendidikan spritual manusia modern. Mengingat di era revolusi industri 4.0 manusia hanya disentuh oleh alam materi sehingga nilainilai spritual terabaikan. Kesimpulan umum penelitian ini adalah di era revolusi industri 4.0 pendidikan holistik berbasis kecerdasan ruhiologi (RQ) mutlak dibutuhkan dalam rangka mengendalikan dampak negatif akibat revolusi industri. Karena secara normatif perkembangan teknologi tidak bisa dibendung tetapi dapat dikendalikan oleh manusia.

\section{DISKUSI}

Menurut Ar-Razi (1990) ruh adalah unsur yang berdiri sendiri. Ia menulis dalam tafsirnya ketika menjelaskan surat Al-Qiyamah ayat 28: 


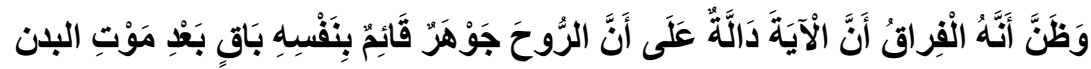

"(saat kematian itulah) ia yakin akan benar-benar berpisah (dengan dunia)" ayat ini menunjukkan bahwa sesungguhnya ruh merupakan unsuryang berdiri dengan dirinya sendiri sesudah kematian badan"

Bahkan menurut Muhammad bin Nashr Al-Marwazi dan Muhammad bin Hazm ruh lebih dahulu diciptakan daripada jasad, sebagimana yang ditulis oleh Ibnu Qayyim Al-Jauziyah (w. 751 H) dalam bukunya "Ruh" (Al-Jauziyah, 2015).

Jika ruh adalah unsur yang indevenden dalam diri manusia maka sudah semestinya perhatian terhadap ruh ini mestinya lebih besar daripada perhatian terhadap unsur materialnya yaitu jasad. Demikian juga perhatian terhadap kecerdasan manusia seperti IQ, EQ, dan SQ semestinya tidak dapat dipisahkan dari keberadaan ruh tersebut. Dengan kata lain, tiga kecerdasan yaitu IQ, EQ, dan SQ mestilah kembali kepada satu unsur utama yang terdapat dalam diri manusia, yang indevenden yaitu ruh.

Selama ini para pakar hanya membedah secara struktural tiga kecerdasan manusia (IQ, EQ, dan SQ) tetapi mereka belum bisa menjawab dari mana asal/sumber dari ketiga kecerdasan itu. Untuk itulah tulisan ini hadir memberikan kontribusi akademis dengan tujuan menyempurnakan ketiga bentuk kecerdasan yang telah ada.

Seperti yang telah penulis uraikan sebelumnya, ketiga kecerdasan manusia itu mestilah kembali kepada satu unsur yang indevenden dalam diri manusia yaitu ruh. Dengan kata lain, ruh menjadi poros terhadap tiga kecerdasan itu serta pengendali atasnya. Di sini, penulis memunculkan istilah kecerdasan ruhiologi atau ruhiologi quetions (RQ). Kecerdasan ruhiologi atau ruhiologi quetions (RQ) adalah kecerdasan yang berasal dari hubungan vertikal antara manusia dengan penciptanya, yaitu Tuhan. Oleh karena itu ia terikat oleh nilai-nilai rabbani. Hal ini tentu berbeda dengan banyak kecerdasan lainnya seperti IQ, EQ, dan SQ yang seringkali bebas nilai sehingga membuat manusia kehilangan ketenangan dan arah tujuan hidupnya.

Kecerdasan ruhiologi atau ruhiologi quetions (RQ) berimplikasi pada perubahan akhlak atau tingkah laku. Untuk mencapainya diperlukan sarana vertikal antara manusia dengan Tuhan. Dalam Islam, sarana vertikal relasi antara manusia dengan Tuhan adalah kewajiban menjalankan ajaran-ajaran agama, di antaranya adalah shalat. Melalui shalat Allah swt. mendidik ruh yang merupakan unsur spritual terbesar dalam manusia, yang merupakan faktor penggerak setiap tindakan dan pemikirannya. Dampak dari pendidikan ruh nantinya akan menghasilkan kecerdasan ruhiologi yang berimplikasi pada perubahan karakter, tingkahlaku, moral, etika, mental, dan akhlak.

Ditetapkannya shalat sebagai sarana pendidikan spritual (ruh) karena dalam diri manusia secara psikologis ada musuh sebangsa hawa nafsu-dunia-syetan. Hal ini dijelaskan oleh Sabda Nabi 
saw: "Musuh yang paling perlu kamu lawan ialah musuh yang ada pada tubuhmu. (HR. Baihaqi)". Karena adanya musuh dalam diri manusia maka manusia berpotensi menjadi mukmin maupun ingkar (kafir). Namun, jika shalat telah telah ditegakkan maka substansi kekafiran tadi yang bersifat engkar, keluh kesah, suka menantang, dan suka berbuat kerusakan di muka bumi dapat dihindari.

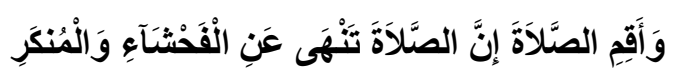

"Dan dirikanlah shalat, sesungguhnya shalat itu mencegah dari perbuatan keji dan mungkar (QS.29:45)

Inilah sebuah konsep yang ditawarkan untuk dunia pendidikan di era revolusi industri 4.0. Yaitu pendidikan yang bernuansa holistik berbasis kecerdasan ruhiologi (RQ) manusia. Metode pendidikan ini tidak mengambil bentuk formal sebagimana siswa duduk di dalam kelas. Metode pendidikan ini dapat dilakukan oleh siapa saja asalkan ia mengetahui unsur utama dalam diri manusia yang indevenden yaitu ruh. Jika pendidikan holistik berbasis kecerdasan ruhiologi ini terlaksana dengan baik maka insyallah krisis multidimensional yang sedang melanda masyarakat modern sebagai akibat dari era revolusi industri 4.0 dapat teratasi. Hal ini dikarenakan semua krisis/kemelut tersebut berasal dari perbuatan tangan manusia sendiri yang dikendalikan oleh sisi dalamnya yaitu "Ruh".

Harus kita akui, dalam zaman kita dewasa ini, di mana berbagai makna kehidupan saling bertarung, yaitu antara keimanan dan keingkaran, antara ruh (spirit) dan benda (materi), antara cita harapan dan putus asa, masyarakat Islam tetap berlindung pada kepercayaannya yang idealistik. Dan perlindungan itu tidak keliru, karena agama memberi kepada masyarakat semua kebajikan yang dipunyainya. Agama juga sama sekali tidak menghalangi masyarakat memperoleh kebajikan sebanyak-banyaknya dari ilmu pengetahuan dan peradaban (Aqqad, 1996).

Bahkan Aisyah Abdurrahman- yang lebih dikenal Bintu Syathi'-mengatakan manusia sungguh tidak pernah dapat hidup dalam situasi hampa agama. Dan bahwa pembaharuan sistem atau ideologi apa pun akan mengalami krisis jika menafikan kenyataan manusia yang tidak melulu materi, manusia memang dapat hidup di dalam sistem sebaru mungkin, namun alam kejiwaannya dikendalikan oleh perasaan-perasaan dan naluri-naluri yang tidak dapat dijelaskan secara materialistik, juga eksistensinya ditentukan oleh rahasia-rahasia yang tersembunyi dan relatif, tidak oleh aksioma-aksioma matematis (Abdurrahman, 1997). 


\section{REFERENSI}

Abdurrahman, A. (1997). Manusia Sensitive Hermeneutika Al-Qur'an. Yogyakarta: LKPSM.

Al-Jauziyah, I. Q. (2015). Hakikat Ruh (I). Jakarta: Qisthi Press.

Aqqad, A. M. A.-. (1996). Filsafat Qur'an: Filsafat, Spritual, dan Sosial Dalam Isyarat Qur'an. Jakarta: Pustaka Firdaus.

Ar-Razi, F. (1990). Tafsir al-Kabir al-Musamma bi Mafatih al-Ghaib. Al-Maktabah As-Syamilah.

As-Shouwy, A. (1997). Mukjizat Al- Qur'an dan As -Sunnah Tentang Iptek. Jakarta: Gema Insani Press.

Bastaman, H. D. (1995). Integrasi Psikologi dengan Islam: Menuju Psikologi Islami, (II, Vol. 9). Yogyakarta: Pustaka Pelajar.

Ghulsyani, M. (1996). Filsafat-Sains Menurut Al-Qur'an (IX). Bandung: Mizan.

Harahap, S. (2015). Islam \& modernitas: Dari Teori Modernisasi Hingga Penegakan Kesalehan Modern. Jakarta: Kencana.

Hawari, D. (1997). Al- Qur'an:Ilmu Kedokteran Jiwa Dan Kesehatan Jiwa (3rd ed.). Jakarta: Dana Bhakti Prima Yasa.

Kuntowijoyo. (1999). Paradigma Islam:Interpretasi Untuk. Aksi. Bandung: Mizzan.

Mulkhan, A. M. (1995). Teologi Kebudayaan Dan Demokrasi Modernitas. Yogyakarta: Pustaka Pelajar.

Nasution, F. (2001). Thibburrubany Atau Faith-Healing; Psikologi Iman Dalam Kesehatan Jiwa Dan Badan (III). Jakarta: Eldine ed.

Sugiarto. (2019). pendidikan-holistik-mengombinasikan- kecerdasan-dan-multiple-intelligence.

Tauhidi, P. N. (2015). Islam Nusantara:Islamisasi Nusantara Atau Menusantarakan Islam.

Yasien Mohamed, F. (1996). Fitrab: Islamic concept of human nature. Ta-Ha Publishers. 